\title{
Deemed Unsuitable for Children: The Editing of Oodgeroo's Stradbroke Dreamtime
}

\author{
Jennifer Jones
}

$\mathrm{O}$ dgeroo of the Tribe of Noonuccal, Custodian of the Land Minjerriba, spent three decades of her life in the public sphere. In the 1960s, known as Kath Walker, she established and consolidated her reputation as a pan-Aboriginal activist and 'people's poet'. Her voice was received as representative of Aboriginal experience and concerns. as she lamented the lack of civil rights, impoverished living conditions, the loss and destruction of traditional cultures and lands. Strident political poems such as 'Aboriginal Charter of Rights' and 'Oration' were first delivered at political gatherings and became catchcries for the political struggle of organisations such as the Federal Council for the Advancement of Aboriginal and Torres Strait Islanders (FCAATSI) and the National Tribal Council. However, for the majority of her public life Oodgeroo spurned this title as people's poet, preferring to be known as an 'Educator'. Rhonda Craven recalls.

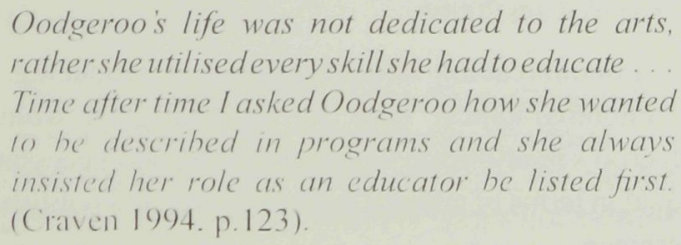

The fact that Oodgeroo's earlier profile as 'Kath Walker, poet and pan-Aboriginal activist' persistently eclipses her important later work as an educator and children's author suggests that white Australia was (is?) not ready to acknowledge the vitality of contemporary Aboriginality that she attempted to communicate. Oodgeroo's discussion of land-rights and her invocation of A boriginal identity among people of mixed Aboriginal descent were far more radical than her previous calls for intangible 'civil rights'. This article argues that Oodgeroo's first prose text, Stradbroke Drecamtime. was adjusted during editorial preparation to accommodate white notions of Aboriginality. Oodgeroo was a seemingly formidable advocate. but muzzling her emerging prose voice proved to be a much easier task than her reputation would indicate. In a sample comparison of Oodgeroo's manuscript with the published text I demonstrate how stereotypes of Aboriginal primitivism subvert Oodgeroo's portrayal of contemporary Aboriginality. As Deborah Bird Rose astutely argues, The resurrection of the my thologised indigene requires that the living survivors be muzzled' (Rose 1997, p.26).

When Oodgeroo wrote and published Stradbroke Dreamtime she had a reputation for her forthright, fiery nature. Oodgeroo had a political history marked by unpopular, independent stances. She made known her intolerance of outside interference with Aboriginal endeavour, both in public statements and in her actions. Oodgeroo had spoken openly and uncompromisingly against white censorship, citing her early encounters with the Communist Party, 'I didn't stay in the Communist Party long because they wanted to write my speeches. They wanted me to say what they wanted me to say. I said, "No, can't do that. I'm no parrot."' (Mitchell 1987, p. 197). Her position on white leadership in Aboriginal rights lobby groups, land rights and conservation groups also serves as a pertinent example of her principled stand against cultural imperialism (Jones 2001; Read 1990).

Unlike other foundational Aboriginal women writers. such as Margaret Tucker and Monica Clare, Oodgeroo did not find a life-long philosophical home within a community of commitment'. Margaret Tucker was a dedicated member of the international Christian movement 'Moral Re-Armament', while Monica Clare was aligned with the Communist Party and other United Front groups. Oodgeroo had a more vexed and provisional relationship with the authoritative discourses and political institutions of her day. She tried and abandoned several political movements including the Communist Party, eventually drawing support from a loose coalition of nationally prominent individuals (such as Judith Wright and Nugget Coombs). Though dedicated, this coalition could not provide the hedging protection that a community of commitment offered through its organisational structure, resources and shared ideals.

The contrasting editorial treatment of foundational Aboriginal women's narratives (all published in the 1970s) stand as examples of the cost and benefits of belonging. Margaret Tucker and Monica Clare both drew amateur editorial assistance from within their friendship circle. Changes to their texts were negotiated, and compromise reached in the interests of the Aboriginal author and the philosophical goals of the sponsoring group (Jones, 2001). Oodgeroo's assertion of political and philosophical independence could 
not protect Stradbroke Dreamtime from being substantially altered by her professional editor.

In 1969-70 a series of personal and institutional crises engulfed Oodgeroo. She abandoned poetry and high profile activism, and retreated to her homeland on North Stradbroke Island. Adapting earlier international struggles such as the Negritude movement and pan-Africanism to the Australian situation, Oodgeroo sought to strategically salvage and reinvigorate Aboriginal culture. She devoted the last two decades of her life to educational projects and prose writing for children. Her best selling children's prose titles published between 1970 and 1992 were as prolific and sold as well as her earlier poetry volumes. Oodgeroo harnessed an integrated politics of education and writing to foster cultural and environmental conservation and to teach anti-racism. Her autobiographical text Stradbroke Dreamtime was an early expression of this approach.

\section{The Editorial Relationship}

The editor of Stradbroke Dreamtime, Barbara Ker Wilson. remembers a sense of trepidation as she met Oodgeroo for the first time.

She was a very feisty lady at that time, and in a sense you felt you were working with a slightly volcanic temperament and that she might easily object to something you 'd done to her manuscript. (Ker Wilson 2000)

However, as I shall demonstrate, Oodgeroo's intimidating reputation for wilfulness did not hinder Ker Wilson's approach to the manuscript, nor did it influence the execution of her editorial task.

British-born Barbara Ker Wilson's polished Oxbridge accent and professional training with Oxford University Press also make an imposing first impression. After immigrating to Australia she managed the Angus and Robertson children's list. She later became an editor for the University of Queensland Press Black Writers series, respected for her professionalism and her long and significant contribution to Aboriginal publishing. Ker Wilson's work with Oodgeroo, however, was her first collaboration with an Aboriginal writer
At the time Stradbroke Dreamtime was nearing completion, Oodgeroo was suffering profound fatigue. This fatigue, combined with a desire to pass her stories down to a younger generation, may well have inhibited Oodgeroo's challenging of editorial decisions. Ker Wilson's professional practice was collaborative in style: she worked only in pencil, inviting the author to engage in a discussion of the proposed alterations. However, it seems that even a bold personality such as Oodgeroo found taking the initiative to object and counter the professional opinion of an experienced editor a difficult prospect:

Kath was inclined too perhaps to take too much of what I suggested ... I think afterwards, I believe she made some remarks about how her manuscripts had been changed, which is always sad for an editor because she did have the opportunity [to object] at the time. (Ker Wilson 2000)

As a groundbreaking writer, engaged in producing the first autobiographical work by an Aboriginal woman, Oodgeroo's relationship with Ker Wilson was necessarily unequal in terms of cultural capital, power and publishing experience.

\section{The First Edition}

The first edition of Stradbroke Dreamtime was designed for a children's market, aimed at an audience nine years and over. It was a $22 \times 17 \mathrm{~cm}$ text with black and white illustrations accompanying each story. The first half of the book, titled 'Stories from Stradbroke' contains autobiographical stories from Oodgeroo's childhood. The second half, titled 'Stories From the Old and New Dreamtime' contains traditional legends and new Dreaming stories told in traditional form. Seven years after initial publication Oodgeroo publicly criticised the publishing house Angus and Robertson, citing her disappointment with the style of illustrations, the editorial treatment and the demeanor of the publishers. Stradbroke Dreamtime was Oodgeroo's only title with Angus and Robertson. Her poetry was published by Jacaranda Press, to whom she returned in 1981, when publishing her second prose book for children, Father Sky and Mother Earth. 
A white man, Denis Schapel was selected by the publishing house to illustrate the first edition. Barbara Ker Wilson recalls his idea for the illustrations was to draw in Aboriginal style (Ker Wilson 2000). This choice, along with many other editorial choices I will identify in this paper, reflects a modernist notion of primitivism. For the cover illustration, the publishers chose a painting done by an Aboriginal child for whom no attribution is given. This painting was originally intended for a calendar project, illustrated by a number of Aboriginal students, that Barbara Ker Wilson was coordinating in cooperation with an inner-city Adelaide school. When this project foied, Barbara Ker Wilson saw the opportunity to use one of the paintings nevertheless.

()odgeroo was not impressed with the packaging and was infuriated by the inability of the publishing house to identify and acknowledge the cover illustrator. The Australian reported Oodgeroo as being disgusted by, "the niggardliness of Australian publishers'

\begin{abstract}
The cover of my last book (Stradbroke Dreamtime) was a painting by a 10-year-old Aboriginal girl and the publishers could not even tell me her name. . That book is compulsoryreading in Japan for children learning English. It is recommended reading in Australianschools and 20,000 have been distributed in Poland. Yet that little girl has not got a cent out of it. That is sick and Australians are sick in the way they treat their Aborigines and their artists. (October $5^{\text {th }} 1979$, p.2)
\end{abstract}

Angus and Robertson's packaging of the first edition of Stradbroke Dreamtime indicates their failure to recognise the value of art as a means of culturally appropriate empowerment for Aboriginal people and a failure to consult appropriately with the author. But Oodgeroo's outburst was also directed at a more significant malaise. Examination of the original manuscript of Stradbroke Dreamtime reveals that there was a clash of expectations between Oodgeroo, and her editor, Barbara Ker Wilson. The manuscript of Stradbroke Dreamtime offers many alternative viewpoints that are filtered out in the published edition by the trope of primitivism, a trope that invents a bygone Aboriginality, not an active contemporary, political identity. The radical potential of Stradbroke Dreamtime was restrained by prevailing understandings of the genres towards which it was edited.

Since Indigenous Australian writers first gained access to mainstream publishers and audiences in the 1970 's the autobiographical genre has been their primary mode of address. In the Western understanding of literary categories, autobiography has been understood primarily as a chronological birth-to-success narrative that traces an individual life. Indigenous writers, however, have significantly adapted the conventions of the genre to suit their particular cultural needs. Indigenous autobiographies are rarely narratives of individual achievement; they are profoundly relational. As communal narratives they draw upon oral histories, collective memories, and spiritual connections to land and kin (Moreton-Robinson 2000) that announce their cultural difference. These adaptations of the genre are not always easy for white readers to perceive. Lack of familiarity with Aboriginal culture and a strong 'inclination to incorporate everything they read into their own experience' (Brewster 1996, p.39) inhibits the recognition of difference. In the case of Stradbroke Dreamtime, Oodgeroo's attempt to adapt the autobiographical genre to more adequately present an Indigenous world-view was eclipsed by white notions of Aboriginal primitivism.

\section{Primitivism and the Western Self}

Primitivism, one of the tropes of a modernist aesthetic, values a pristine and bygone Aboriginality that can be appropriated on demand and used as a supplement to white lives. Traditional legends, such as those in Stradbroke Dreamtime, are interpreted through the lens of primitivism as dead cultural artifacts, not as the voice of a living spirituality. Collections such as Australian Legendary Tales by Katharine Langloh Parker, for example, encourage a reading informed by popular paradigms of evolutionary theory that viewed Aboriginals as both 'an anachronistic race and expiring people' (Dalziell 2002, p.333). Texts which seek to preserve the tales of a static or 'dying' culture are designed to meet the needs of the white reader, not the Indigenous subject, whose perspective would certainly differ considerably. In this way the primitive remains a static, voiceless Other that functions to mirror the concerns and obsessions of the Western self: 
The needs of the present determine the value and the nature of the primitive. The primitive does what we ask it to do. Voiceless, it le ts us speak for it. It is our ventriloquist's dummy... The primitive can be - has been, will be (?) whatever Euro-Americans want it to be. It tells us what we want it to tell us. (Torgovnick 1990, p.9)

Nostalgia for the imagined simplicity of the past motivates the admiration of the primitive. Indigenous spirituality, including connections with land or ancestors, is denied contemporaneity and political efficacy by its classification as folklore. As I argue elsewhere, editorial changes to Stradbroke Dreamtime deny coevalness between Aboriginal and settler societies by resituating the story in the Western conception of a removed mythical 'golden age'. not the every when of Alcheringa or the Dreaming. which accommodates contemporary realities (Jones 2002).

Just as Oodgeroo's political work had aimed to overcome legacies of colonialism in the life of her community, she also struggled to overcome legacies of colonialism in her life as a writer. As I illustrate below, the manuscript version of Stradbroke Dreamtime challenged white perceptions of contemporary Aboriginality and the political role and potential of emerging Aboriginal literary expression. Published as a folk-lore text for children and reviewed by anthropologists (Jones 2001, p. 190), the first edition of Stradbroke Dreamtime was framed and impinged upon by neocolonial attitudes towards Aboriginal art. The editorial and generic shaping of Stradbroke Dreamtime significantly depoliticised Oodgeroo's prose to meet the publisher's market expectations of her chosen tool. In manuscript form, Stradbroke Dreamtime crossed genre boundaries and pushed the limits of acceptable Aboriginal expression as determined by white cultural criteria, which insisted on situating Aboriginal work in an innocent past. The edited version of Stradbroke Dreamtime achieved very different aims. Stradbroke Dreamtime became a popular children's title that sold out four editions. This popular success was secured by the style of editorial emendation to the manuscript. particularly through the imposition of traditional Western genre expectations for autobiography and folklore.

\section{The Manuscript}

The manuscript of Stradbroke Dreamtime is housed in the Oodgeroo Noonuccal collection at the University of Queensland's Fryer Library. The manuscript exists in three forms: hand-written drafts, final drafts typed by the author, and the edited proofs. Stradbroke Dreamtime is an unusual text because of the deliberate generic combination of autobiographical stories and tribal legends. The manuscript of Stradbroke Dreamtime merges these generic forms, demonstrating the present-continuous nature of the Dreaming in Aboriginal cosmology where the integrating of life story with folklore maintains continuity between the cultural past and present, and acknowledges the role of the Dreaming in the daily lives of Aboriginal people and their communities

\section{Editorial alterations to the text prior to publication included} dividing the autobiographical stories and tribal legends along generic lines. Passages deemed as inappropriate or unacceptable representations of Aboriginality were substituted with an image more akin to the mythologised Indigene of the white modernist imagination. This included the removal of sections that openly criticised the dominant culture or referred to white racist behavior. Changes of this tenor divorced Stradbroke Dreamtime from the everyday political experiences of Aboriginal people and disarmed Oodgeroo's mobilisation of children's literature as a cultural educational and anti-racist tool. Differences between the manuscript and published versions of Stradbroke Dreamtime thus illustrate a profound clash of expectations regarding the function and political value of children's literature, transforming it from a challenging educational tool to the level of entertainment which perpetuated dominant white cultural perceptions and reinforced the racial status quo. A close textual comparison of the manuscript and the published text identified a total of 1219 changes to the original manuscript. Within this total 61 alterations had negative outcomes for the text. Negative outcomes are included in the table below: 
Editorial Changes to Stradbroke Dreamtime: 61 significant alterations from a total 1219 editorial changes

\begin{tabular}{|c|c|c|}
\hline 1. & $\begin{array}{l}\text { Deletes reference to adult life } \\
\text { of child character }\end{array}$ & 2 \\
\hline 2. & Deletes Aboriginal English & 2 \\
\hline 3. & $\begin{array}{l}\text { Non gendered address } \\
\text { changed to masculine }\end{array}$ & 2 of 14 stories \\
\hline 4. & $\begin{array}{l}\text { Raises the 'respectability' of } \\
\text { the character }\end{array}$ & 3 \\
\hline 5. & Change of title & 3 \\
\hline 6. & $\begin{array}{l}\text { Stories told in 3rd person al- } \\
\text { tered to autobiographical ' } \mathrm{I} \text { ' }\end{array}$ & 3 stories \\
\hline 7. & $\begin{array}{l}\text { Deletes or reduces relation- } \\
\text { ship and communication } \\
\text { with nature }\end{array}$ & 4 \\
\hline 8. & $\begin{array}{l}\text { Aboriginal culture described } \\
\text { in past tense or reference to } \\
\text { present experience deleted }\end{array}$ & 4 \\
\hline 9 & $\begin{array}{l}\text { Deletes ty pographic design in } \\
\text { Dreamtime section }\end{array}$ & 6 of 14 stories \\
\hline 10. & $\begin{array}{l}\text { Deletes or reduces details } \\
\text { that reflect badly upon or } \\
\text { disturb white majority (race } \\
\text { relations/hardship) }\end{array}$ & 10 \\
\hline 11. & $\begin{array}{l}\text { Deletes references to } \mathrm{Ab} \text { - } \\
\text { original knowledge/spiritual- } \\
\text { ity/practices }\end{array}$ & 11 \\
\hline 12. & $\begin{array}{l}\text { Deletes or reduces the pri- } \\
\text { macy of Aboriginal perspec- } \\
\text { tive (imposes view of white } \\
\text { majority especially regarding } \\
\text { Aboriginal rights) }\end{array}$ & 12 \\
\hline Total & & 61 \\
\hline
\end{tabular}

The table above lists significant alterations that $I$ identified from among the 1219 total changes to the manuscript. The most significant changes occur more frequently and relate to the reduction or deletion of contemporary Aboriginal perspectives on Aboriginality and cross-cultural relations.
In the following section I will examine Oodgeroo's story 'Mumma's Pet', as an example of the editorial changes. 'Mumma's Pet' is the story of a billy-cart game that goes wrong, resulting in a broken arm and a dangerous boat trip to a mainland hospital. This tale of sibling rivalry was not one of the most profoundly altered stories in the collection. Indeed, the changes could be viewed as minor. However, close consideration of even apparently insignificant alterations reveals how Oodgeroo's political intentions are undermined and how the tenor of the story is transformed from a grounded and colloquial recollection of personal experience into the universal voice of a "girls own' moral tale. As the story is brief, the manuscript version is reproduced in full, inserting the alterations made before publication in bold brackets.

\section{Mumma's Pet}

Dad had built a billy-goat cart for us. Dad always built things to last, and this was a sturdy, heavy construction. It consisted of two large bicycle wheels and a wooden-box frame. It looked like a large box on wheels with two shafts protruding from it

We used the cart for all sorts of carrying jobs. One of us - usually me - would back into the cart like a like a horse (billy-goat), take hold of the shafts, and pull while the others pushed from behind. When the cart wasn 't in use for some labouring job or other, we children used it in our playtime (often played with it). Our lawn was buffalo grass (our garden was covered with buffalo grass), which tends to creep over everything in its way. As we lived so near the swamp marshes, it grew quick, green and abundant. We became expert at racing the billy-goat cart over the grass, especially where small dirt mounds were sticking out of the ground (where small dirt mounds, grass-grown, stuck above the ground). It didn't matter how rough (roughly) we treated that cart, it just took all our (all the) punishment; such was Dad's carpentry, we didn't even lose a nail (Dad's carpentering was so thorough that it didn't even lose a nail).

One day my elder sister decided on a new game. (One day my sisters and I decided to play with the cart by ourselves. My elder sister often showed resentment of my younger sister; she used to call her 'Mumma's pet' it was true that Mother was inclined to make more of 
a fuss of my younger sister, and as a result she was a bit spoilt. Today, however, we were playing happily together, good friends for once.) She thought it would be more fun (it would be fun) to put our younger sister in the cart and for me - as usual - to be the billy-goat while she pushed from behind.

We were going great and my younger sister was yelling with excitement. while my elder sister ordered me to pull my weight and stop being lazy. I wasn't being lazy; I was putting in all I could into pulling the cart and I was working at top speed (deletes 'working at top speed'), but it was a puny effort compared to my elder sister's unlimited strength. Carried away by the excitement of the game, my elder sister tried to get more effort out of me by pushing harder. We were going round and over the bumpy grass tussocks when suddenly my puny strength gave out, I lost my balance. and the cart tipped over.

My younger sister went sprawling over the side of the cart as I tried to regain my balance - but the cart was too heavy for me. and as she fell, one wheel came down on top of her outstretched arm. I fell on top of her and my elder sister fell on top of me. Our younger sister let out a yell of pain She always did that whether she was hurt or not

Finally we got ourselves sorted out, and righted the cart. Our younger sister was holding her arm and whimpering away (whimpering). My elder sister took one look at her and told her to stop play-acting. My younger sister was a bit spoilt and Mum always fell for her play acting. (Deletes 'My younger sister was a bit spoilt and Mum always fell for her play acting'). She never tired of trying to impress us with her acts - though she never succeeded with us the way she did with Mum (Mother). Still holding her arm and crying. she said. 'I'm going to tell on you both (I' $\mathrm{m}$ going to tell Mum). You hurt me!

My elder sister was furious (Deletes 'My elder sister was furious'). 'Why don't you grow up - instead of expecting to stay a cry-baby all your life (Deletes 'all your life'), Mumma's little pet,' she sneered (my elder sister retorted furiously).

'You did hurt me,' insisted my young sister (my younger sister whimpered).
'All right, so we hurt you. Well, that means you have the right to hurt us back. That's fair, isn't it? You can hit us as hard as you like, provided you don't tell Mum what happened.'

My younger sister was angry so she (So my younger sister) walloped into us both with the arm that hadn't been hurt. 'Take that, and that. and that.' she kept yelling as she hit us. ('Take that' she kept yelling as she hit us again and again.)

My elder sister winced in mock pain, and cried out for my younger sister to go easy and not hit so hard. She was a great ham actor herself.

We decided we should go home and put the cart back in the tool shed (We decided we should put the cart back in the tool shed and go indoors). My younger sister dragged along behind us, not talking (speaking) to us.

During the evening meal my elder sister and I watched her out of the corners of our eyes, wondering whether she would squeal on us. We didn't really trust her in spite of the pact we'd made. But our mother (my mother) noticed that her youngest daughter was eating very little and was strangely silent. Even stranger still, she never said a word: she just sat there with a strained expression on her face (Her face had a strained expression, too). Eventually Mum called her to the head of the table.

'Ted, 'she said, 'this girl looks sick to me.

Dad looked over his glasses at his youngest daughter. (Deletes 'over his glasses') 'Come here. girl,' he ordered.

He ran his hand gently down the arm she had half lifted; it looked stiff against her body. She suddenly gave a scream of pain. It sounded genuine all right. My older sister and I exchanged glances.

'Mum, this girl's arm is broken. I think,' Dad said as he further investigated the damaged arm (Deletes 'as he further investigated the damaged arm').

'How did you hurt your arm?' ('How did it happen?') Mum asked our sister, but she just looked towards us with pained eyes, while we stared back at her with vacant expressions. 
Dad summed up the situation fast.

'All right,' he said, turning to my elder sister, 'what the hell were you up to today? ('what have you been up to?') How did this girl get hurt?'

My elder sister blurted out the story of the billy-goat cart 'We were only giving her a ride in the cart,' ('We were only playing together') she finished lamely.

'Well, she's got a broken arm for your trouble, and how the hell are we going to get her to a doctor? You know the doctor on this island only attends to white people. He won't treat Aborigines.' Dad was furious. ('Well,' Dad said, 'she's got a broken arm as a result of your playing, and how are we going to get her to a doctor? You know the doctor here only attends to white people. He doesn't treat Aborigines.' Dad was really angry.)

Mum cuddled our younger sister and made soothing noises as Dad gave out orders (instructions) to our brothers. 'Row out to the channel and see if any boat is prepared to take her to a doctor on the mainland. Let's hope there's some white person out there with some decency in them. ' ('Let's hope there's a decent white man out there.')

My brothers ran off to the dinghy, and they did find a white man who came to the rescue. He placed his auxiliary yacht, Flockwing, at father's disposal and acted as his offsider on the boat. (He placed his auxiliary yacht, Flockwing, at father's disposal and I acted as Dad's offsider on the boat.) They set sail with a stiffening breeze blowing and a storm brewing in the west. The weather turned very rough. During the trip the mast snapped and fell. narrowly missing my younger sister. then the main sail was carried away by the wind. (During the trip the weather turned very rough, but luckily the engine kept going.) My sister's condition worsened, and she was violently ill. When they reached the mainland, the doctor put her in hospital for the night. She was suffering from shock and seasickness as well as her broken arm.

What happened to my elder sister and me? We got the hiding of a lifetime from Mum - who by the way, was one of the strongest women I've ever known (Deletes 'who by the way, was one of the strongest women I've ever known'). When she got angry, she could pack a wallop (she could wallop good and hard).

When my younger sister returned from the hospital, she was treated like a V.I.P - both Mum and Dad spoilt her rotten. She took full advantage of this situation. We bowed to every demand she made of us during her convalescence, but otherwise we tried to keep out of her way as much as possible (My elder sister and I kept out of her way as much as possible during her convalescence).

After her arm had healed, things almost returned to normal (everything returned to normal). We made a few alterations to the billy-goat cart, but we made her watch, rather than participating in any more games we cooked-up. My elder sister still resented the whole episode and grumbled quietly each time she saw the new smirk on my younger sister's face.

'Damn Mumma's pet,' she whispered. She always smiled as she said it, just in case our younger sister was watching

(Deletes entire final paragraph, replaces with, 'But we never asked her to join in any games with the billy-goat cart again')

The most obvious impact of these editorial changes relates to the reduction of the colloquial voice of the story. The manuscript version includes colloquial expressions such as 'pack a wallop' and 'cooked-up', 'what the hell' and 'how the hell' which add a realistic local quality and intensity. In other stories a distinctive Aboriginal voice is deleted, particularly in the thoughts and expressions of Oodgeroo's mother in 'The Tank' and 'The Carpet Snake'. In 'The Carpet Snake', Oodgeroo's mother finds her husband Ted's pet carpet snake in the cot with her newborn baby The edited version reads. But you mark my word. you stubborn fellow, that snake could have swallowed my baby' (Walker 1972, p.48). This has none of the flavour or the intensity of the manuscript version, 'You mark my word, damn fool stubborn man, that snake is gonner swaller my baby, you wait and see' (Walker, Manuscript). The published version of Stradbroke Dreamtime offers a very straight-laced, Anglocentric characterisation of Oodgeroo's family, for example, calling Mum, 'Mother' throughout. The contrast between the two versions of the dinner table scene, is particularly striking. The published 
version reads, Mother noticed that her youngest daughter was eating very little and was strangely silent. Her face had a strained expression, too.' (Walker 1972, p.62) This holds none of the colloquial understatement of the manuscript version, 'Even stranger still, she never said a word; she just sat there with a strained expression on her face. (Walker, Manuscript). This style of editorial alteration could be attributed to the continuing 'cultural cringe' of the 1970s which promoted the 'Queen's English' as the appropriate standard for all, perhaps the desire for an international audience, and/or the editor's unfamiliarity with working class Australian/Aboriginal culture. All low level swearing is removed from Stradbroke Dreamtime. a decision undoubtedly based on the perception that any swearing is unsuitable for children, even if the removal impoverishes the drama of the narratives. Ted's response to the discovery of his daughter's broken arm illustrates this point. The published version reads;

\section{"Well," Dad said, "she's got a broken arm as a result of your playing, and how are we going to get her to a doctor? You know the doctor here only attends to white people-He doesn't treat Aborigines." Dad was really angry. (Walker 1972, p.63)}

The editorial treatment of this section downplays the impact of the local Doctor's racism by changing a few vital words. The removal of swear words dilutes Ted's angry response and hinders the impact of this moment of family crisis. The manuscript version reads:

'Well, she's got a broken arm for your trouble, and how the hell are we going to get her to a doctor? You know the doctor on this island only attends to white people. Hewon't treat Aborigines. "Dadwas furious (Walker; Manuscript)

Verbal intensifiers such as 'how the hell' support the later description of Ted as 'furious' and draw attention to social causes of his anger. In the manuscript version the description of the doctor as 'the doctor on this island' draws attention to the isolation of Oodgeroo and her family and communicates the profound difficulty that Aboriginal people faced when seeking equitable medical attention, which was only available on the distant mainland. The editorial alteration of this phrase to 'the doctor here' cooperates with another key change to reduce the political impact of this section. The manuscript version lays full responsibility upon the racist Doctor, who 'won't treat Aborigines'. The word 'won't' makes the racist decision an active and ongoing choice to refuse service. The editorial alteration to 'He doesn 't treat Aborigines' down plays the crisis, masking the racist refusal as an administrative choice.

The emergency trip to hospital on the mainland reveals another important change that deflects criticism of the behaviour of white people. The published version has Ted sending out his sons to search for 'a decent white man out there' (Walker 1972, p.63) to take them to the mainland. The manuscript version is crucially different. Ted is much less optimistic as to his quest for decency within the white community. He actually hopes for 'some white person out there with some decency in them' (Walker, Manuscript). Ted does not expect a wholly decent white person to meet his needs; he is realistic in his hopes for a small measure of decency. When found, the published version has this white man place 'his auxiliary yacht, Flockwing, at father's disposal and I acted as Dad's offsider on the boat' (Walker 1972, p.63). A generous act, but a much less humble transaction than the manuscript describes. The manuscript version reads, 'He placed his auxiliary yacht, Flockwing, at father's disposal and acted as his offsider on the boat' (Walker, Manuscript, my emphasis). The manuscript version has the white yacht owner acting as Ted's offsider. Here the white man shows respect to a black man by deferring to Ted's superior knowledge of the coast and seafaring ability. The published version places the child Oodgeroo in this position as offsider, thus preventing this act of hierarchical inversion.

Perhaps the most profound alteration to the writer's intentions for the story 'Mumma's Pet' lies in the removal of the 'sting in the tail'. The published version explains the conflict between the sisters early in the story, by inserting a contextualising paragraph,

My elder sister often showed resentment of my younger sister; she used to call her 'Mumma's pet' - it was true that Mother was inclined to make more of a fuss of my younger sister; and as a result she was a bit spoilt. Today, however, we were 
plaving happily together; good friends for once. (Walker 1972. p.61)

This paragraph does not appear in the manuscript. In the manuscript version the older sister 'has the last say' and secretly grumbles about her spoilt younger sister. The basis for the conflict between the sisters is never overtly stated, as it is in the published version. The manuscript allows the children's actions to speak for the underlying psychological drama. The manuscript version reads:

\begin{abstract}
After her arm had healed, things almost returned to normal. We made a few alterations to the billygoal cart. hut we made her watch, rather than participating in any more games we cooked-up. I/1 elder sister still resented the whole episode and grumbled quietly each time she saw the new smirk on my younger sister's face. 'DamnMumma's pet, 's he whispered. She always smiled as she said it, just in case our younger sister was watching. (Walker, Manuscript)
\end{abstract}

By contrast. the published version reads, 'After her arm had healed, everything returned to normal. But we never asked her to join in any games with the billy-goat cart again. (Walker 1972, p.63). This ending removes the dynamic conflict between the siblings, which provided the rationale for the story in the first place. This style of editorial alteration reflects the editor s conception of the child audience. The changes reflect a desire to isolate childhood as an era of innocence. where wounds heal and everything returns to normal'. It is significant for the emerging Aboriginal literary voice that this view of normality could not accommodate politicised views, particularly experiences of racism that would have embarrassed or confused white readers. Plainly, the measure of 'normal' is dictated and controlled by the dominant white culture. Oodgeroo's manuscript version of 'Mumma's Pet' is much more realistic; it manages to hold spite. vengeance and experiences of discrimination in dynamic tension with the happy family situation also described. The editorial removal of this evidence of conflict within Oodgeroo s family shields the projected children's hook readership from unpalatable complexity in family relationships. contributing further to the view of childhood as a period of innocence, but also perpetuating the modernist image of the infantilised primitive.
The figure of the childlike native has served as a powerful rhetorical device and motive behind practices of repression and abuse, informing colonial practice in every aspect from religious indoctrination to labour laws and the granting of basic political rights' (Fabian 1983, p.63). Removal of references to Oodgeroo's adult life, evidence of family conflict, and the removal of political polemic and experiences of racist discrimination assist this infantilisation by presenting an idealised picture of native simplicity and innocence.

The editorial alterations I have examined in 'Mumma's Pet'soften the narrative and downplay themes that would have shaped Stradbroke Dreamtime into a powerful political and educational tool. Oodgeroo hoped that if young non-Indigenous children had significant Aboriginal contact. this would mould their lifeways towards tolerance and understanding, before the ingrained racist attitudes of their parents were passed down. Oodgeroo commented, 'I'm sick and tired of talking to mentally constipated adults; they don't listen. It's the children who are going to change this world for the better, not the adults' (Lane 1979, p.33). When Oodgeroo abandoned poetry and pan-Aboriginal activism she also abandoned her quest for an adult audience. The publication of Stradbroke Dreamtime coincided with the establishment of the cultural centre at 'Moongalba' and the commencement of its children's education program. When Oodgeroo died in 1993 she had hosted around 30,000 children and adults at 'Moongalba'. Oodgeroo's new focus on children's literature enabled her to reach out to the children who could not travel to Stradbroke Island. The manuscript version of Stradbroke Dreamtime suggests that Oodgeroo intended to communicate a contemporary Aboriginal world view to a wide audience of children. The published version denied Oodgeroo this opportunity by muffling the radical voice of text. In the end, Stradbroke Dreamtime remained tethered to the stereotypes of romanticised Aboriginal primitivism it sought to eschew

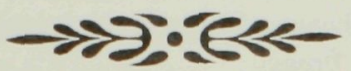




\section{REFERENCES}

Brewster, Anne (1996) Reading Aboriginal Women's Autobiography. Sydney, Sydney University Press.

Craven, Rhonda (1994) 'Oodgeroo as educator', in Shoemaker, Adam (ed) Oodgeroo: A Tribute. St Lucia, University of Queensland Press, pp. 121-30.

Dalziell. Tanya (2002) "'We should try, while there is yet time, to gather all the information possible of a race fast dying out": Unsettleing Sympathetic Women', Australian Feminist Studies 17. 39: 325-42.

Fabian, Johannes (1983) Time and the Other: How Anthropology Makes Its Object. New York, Colombia University Press.

Jones, Jennifer (2000) 'The Black Communist: The contested memory of Margaret Tucker', Hecate 26, 2: 135-143.

Jones, Jennifer (2003) 'Oodgeroo and her editor', Journal of Australian Studies 76: 47-55.

Jones. Jennifer Anne (2001) ‘Aboriginal women's autobiographical narratives and the politics of collaboration'. PhD thesis. University of Adelaide

'Kath Walker closes the book on local publishers', The Australian 5 October, 1979, p.2.

Ker Wilson, Barbara (2000) 'Barbara Ker Wilson interview with Jennifer Jones'.

Lane, Terry (1979). As the Twig is Bent. Melbourne, Dove Communications.

Mitchell. Susan (1987) The Matriarchs: Twelve Australian Women Talk about theirLives to Susan Mitchell. Ringwood. Penguin Books.

Moreton-Robinson. Aileen (2000) Talkin' Up To The White Woman. St Lucia, University of Queensland Press.

Parker, Katharine Langloh (1896) Australian Legendary Tales: Folk-lore of the Noonah- burrahs as Told to the Piccaninnies. London and Melbourne, David Nutt; Melville, Mullen and Slade.

Read, Peter (1990) 'Cheeky, insolent and antiwhite: the split in the Federal Council for the Advancement of Aboriginal and Torres Strait Islanders - Easter 1970', The Australian Journal of Politics and History 36, 1: 73-83.

Rose, Deborah Bird (1997) 'The year zero and the north Australian frontier', in Rose, Deborah Bird and Clarke, Anne (eds) Tracking Knowledge in North Australian Landscapes. Canberra, Australian National University Press: 19-35.

Torgovnick, Marianna (1990) Gone Primitive: Savage Intellects, Modern Lives. Chicago, University of Chicago Press.

Walker, Kath (Oodgeroo) (1972) Stradbroke Dreamtime. Sydney, Angus and Robertson.

Walker, Kath (Oodgeroo) (n.d.) 'Stradbroke Dreamtime', ms. Oodgeroo Collection no. 84: St. Lucia, Fryer Library, University of Queensland.

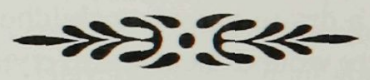

\section{BIOGRAPHICAL NOTE}

Jennifer Jones is a Post Doctoral fellow at the Australian Centre, University of Melbourne. Her scholarly interests include Aboriginal literature and history, whiteness studies and contemporary Australian literature. Her current research focuses upon foundational Aboriginal author Ella Simon, her establishment of the first Aboriginal branch of the Country Women's Association at Purfleet mission and successful collaboration with white women from the Taree district. Jennifer has recently completed a new, re-edited edition of Stradbroke Dreamtime that repatriates important excised material. It will be published by The Vulgar Press in October 2004. 